\title{
pC6-2/caspase-6 system to purify glutathione-S- transferase-free recombinant fusion proteins expressed in Escherichia coli
}

\author{
Prabhat Kumar Purbey, P Cyril Jayakumar, Milind S Patole \& Sanjeev Galande \\ National Centre for Cell Science, NCCS Complex, Ganeshkhind, Pune 411007, India. Correspondence should be addressed to S.G. (sanjeev@nccs.res.in). \\ Published online 16 November 2006; doi:10.1038/nprot.2006.310

\begin{abstract}
Glutathione-S-transferase (GST) fusion protein expression vectors are often employed for the expression and purification of proteins in Escherichia coli. GST is then removed by site-specific proteolysis using thrombin. However, the presence of internal thrombin cleavage sites in expressed proteins can severely affect the purification of intact proteins. Cysteine-dependent aspartate-specific proteases (caspases) are efficient enzymes with defined substrate specificity. Unlike most of the proteases used for the removal of affinity tags, caspases do not leave any amino acids at the amino-terminus of cleaved proteins. We have engineered the caspase- 6 site VEMD in a pGEX vector to give the pC6-2 vector. The caspase- 6 can be easily removed after cleavage. Here, we describe the detailed protocol for purifying proteins using our $\mathrm{pC} 6-2 /$ caspase- 6 expression and purification system. The cleavage by caspase- 6 occurs in $<30$ min and the entire procedure can be completed in $2 \mathrm{~d}$.
\end{abstract}

\section{INTRODUCTION}

Glutathione-S-transferase (GST) fusion protein expression vectors are widely used for the high-level expression and subsequent purification of proteins in Escherichia coli ${ }^{1,2}$. Glutathione sepharose-bound GST fusion proteins can be eluted competitively using reduced glutathione, under conditions mild enough not to affect the antigenicity and activity of expressed proteins. However, GST is a $26-\mathrm{kDa}$ relatively bulky tag that might affect the functional and structural properties of the protein under investigation, making its removal highly desirable. The pGEX vectors contain thrombin, factor Xa or PreScission protease recognition and cleavage sites downstream of GST. Among these, thrombin is widely used to remove the GST tag. However, the presence of internal thrombin cleavage sites in the expressed protein can cause difficulties when using this vector system for the expression and purification of intact proteins $s^{3,4}$. Additionally, relatively extended incubation times $(4-16 \mathrm{~h})$ are required to ensure complete cleavage by all three of the proteases listed above. Sensitive proteins might lose their biological activity during such prolonged incubation periods. Most of the proteases used for the removal of various affinity tags leave one or two amino acids at the amino (N)-terminus of the cleaved protein, which might affect its structural and functional properties. To circumvent these limitations in existing technology, we engineered an expression vector containing a caspase-6 cleavage site (Fig. 1). This site, which we termed as C6, is rarely found in naturally occurring proteins, cleaves the carboxy (C)-terminal to its short recognition sequence leaving no residual amino acids at the $\mathrm{N}$ terminus of the protein of interest and can yield cleaved product in a relatively short period $(<1 \mathrm{~h})$. The protease caspase- 6 used for the removal of tags is expressed and purified as a histidine-tagged recombinant protein and can be easily removed using nickel affinity chromatography, otherwise it remains as a contaminant in the protein preparation (schematically depicted in Fig. 2).

Cysteine-dependent aspartate-specific proteases (caspases) are efficient enzymes with defined substrate specificity ${ }^{5,6}$. The recognition sequences for all caspases consist of four amino acids with aspartate at the last (P1) position ${ }^{5,6}$. Caspases have been cloned, affinity purified and characterized extensively ${ }^{7}$. We therefore reasoned and demonstrated that engineering a caspase site might be useful in the removal of tags. Special AT-rich binding protein 1 (SATB1) is a T-cell-enriched matrix-attachment region (MAR)binding protein that is cleaved by caspase- 6 at the ${ }^{251}$ VEMD $^{254}$ site early during thymocyte apoptosis ${ }^{8}$. As our laboratory is interested in understanding the role of SATB1 in the regulation of chromatin

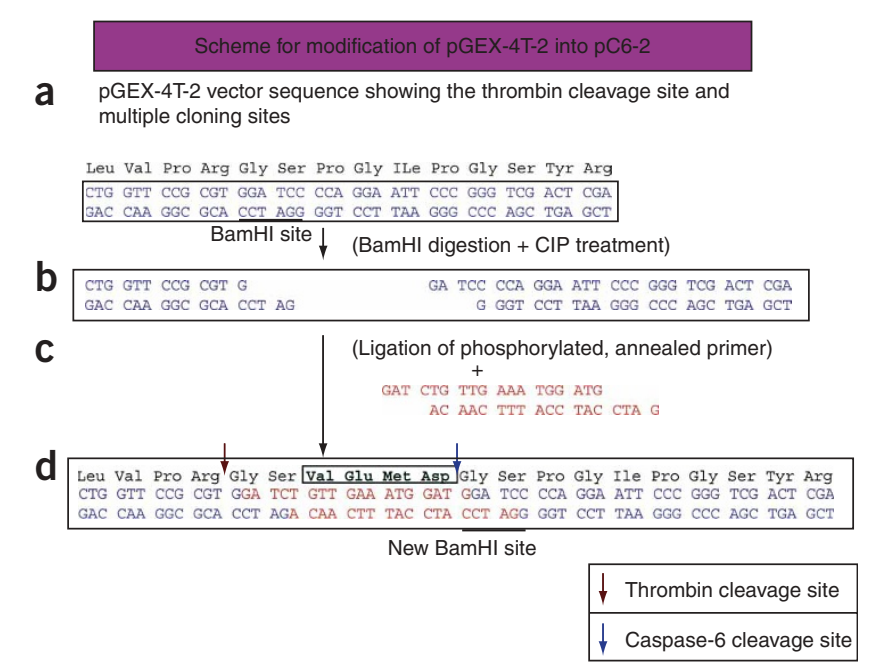

Figure 1 | Schematic representation of the strategy employed to construct the $\mathrm{pC} 6-2$ vector from the parent $\mathrm{pGEX}-4 \mathrm{~T}-2$ vector. (a) DNA sequences surrounding the MCS region of pGEX-4T-2 are depicted. (b) Restriction digestion of pGEX-4T-2 with BamHI generates the sticky ends as depicted. (c) Casp6F and Casp6R primers upon annealing generate the BamHI cohesive ends; therefore, they can be ligated directly into the BamHI digested vector. (d) The DNA sequence of the $\mathrm{pC6}-2$ vector at the MCS region upon ligation of the Casp6F and Casp6R annealed oligonucleotides into the pGEX-4T-2 is depicted. One of the BamHI sites is lost but that at the MCS region is regenerated in the $\mathrm{pC} 6-2$ vector. 


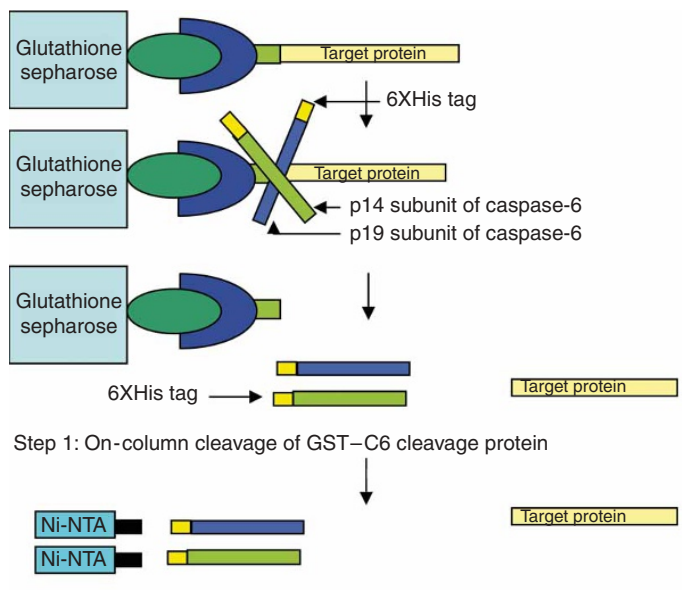

Step 2: Elution of cleaved target protein

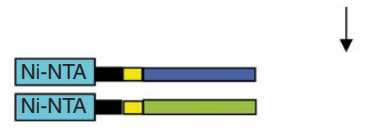

Step 3: Removal of caspase-6 by passing through Ni-NTA column $\downarrow$

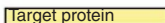

Step 4: GST-free and caspase-6-free target protein

Figure 2 | Schematic representation of on-column cleavage of the GST-C6 fusion protein by caspase-6. Step 1 involves washing and equilibration with caspase buffer, after which the column bound GST-C6 fusion protein is incubated with affinity-purified caspase-6 to allow cleavage for 15-30 min. Step 2 involves elution of the caspase-6-cleaved protein using two to five volumes of buffer $X$; the eluted sample contains traces of caspase-6. Step 3 involves the removal of caspase- 6 after passing the buffer-exchanged caspase-6-cleaved sample through an Ni-NTA column; caspase-6 is retained on the column. In Step 4, GST-free and caspase-6-free target protein is collected as flow-through.

architecture and gene expression, we chose this site from SATB1 for the design of the vector, although other variant caspase-6 recognition sequences (such as VEID) also work equally well.

We have shown that the caspase- 6 cleavage site works in a more efficient and specific manner than the typically employed factor Xa or thrombin cleavage site. We engineered a caspase- 6 site downstream of the thrombin cleavage site in the pGEX-4T-2 vector (Amersham Biosciences). Two oligonucleotides, casp6F (5'-GATCTGTTGAAATGGATG-3') and casp6R (5'-GATCCATCC ATTTCAACA- $3^{\prime}$ ), were designed ${ }^{9}$ to generate a short synthetic DNA fragment upon annealing. This fragment includes the recognition site for caspase- 6 and preserves a downstream BamHI site upon ligation into the BamHI digested pGEX-4T-2 expression vector. The oligonucleotides were designed according to the codon usage in E. coli (http://www.kazusa.or.jp/codon/E.html). The annealed oligonucleotide was phosphorylated at the $5^{\prime}$ end and ligated with the BamHI digested and dephosphorylated pGEX-4T2 vector, which was then used to transform competent $E$. coli strain DH5 $\alpha$ cells (Invitrogen). Transformants were screened by PCR using the casp6F primer and a pGEX-4T-2 vector-specific reverse primer ${ }^{9}$. After confirmation of the sequence of the multiple cloning site (MCS) and caspase- 6 site, we named the modified pGEX-4T-2
TABLE 1 | List of naturally occurring proteins cleaved by caspase- 6 .

\begin{tabular}{lc}
\hline Protein & Reference \\
\hline SATB1 & 8 \\
Cytidylyltransferase- $\alpha$ (CCT- $\alpha$ ) & 23 \\
Transcription factor-activating protein $2 \alpha(\mathrm{AP}-2 \alpha)$ & 24 \\
Transmissible gastroenteritis coronavirus (TGEV) & 25 \\
$\quad$ nucleoprotein (N) & \\
Lamin A and C & 26 \\
Huntingtin & 27 \\
5-lipoxygenase & 28 \\
Periplakin & 29 \\
Notch 1 receptor & 30 \\
Tau & 31 \\
Guanylate cyclase- $\alpha 1$ & 32 \\
Desmin & 33 \\
\hline
\end{tabular}

Only these proteins cannot be purified in full length by the pC6-2/caspase- 6 system.

vector as the pC6-2 vector (Fig. 1). The plasmid constructs for the cloning and expression of the cDNA of interest (pC6-2), and for the expression of caspase- 6 , are both available to research groups from non-profit organizations upon request.

For several functional studies, we have purified various domains of SATB 1 and the $\mathrm{N}$-terminal region of p53 in milligram quantities in our laboratory. We exemplify the use of the pC6-2/caspase-6 system for the purification of two different regions of SATB1, comprising residues $1-204$ and 255-763, in this protocol. The first region contains the PDZ domain of SATB1, which is required for the dimerization of SATB1 (ref. 8) and has been experimentally found to possess an internal thrombin site ${ }^{9}$. The second region harbors the MAR-binding domain (MD) ${ }^{10}$ and homeodomain $(\mathrm{HD})^{11}$. The system also works efficiently for sarcosyl-solubilized and refolded proteins ${ }^{9}$. We have designed primers with ClaI and SalI linkers, and cloned them into pGEX-4T-2; the new plasmid constructs are designated as pC6-2 ClaI and pC6-2 SalI. To accommodate these changes, the caspase- 6 site had to be changed to VEID instead of VEMD, although both work equally well. Using these two restriction sites for cloning, one can eliminate any vector-derived amino acids at the $\mathrm{N}$-terminal. A similar strategy has been employed by Feeney and colleagues ${ }^{12}$ for engineering the caspase- 3 cleavage site into GST fusions. The specific advantage of using caspase- 6 is that, until now, only 12 naturally occurring proteins have been reported as its targets (listed in Table 1); by contrast, the list of targets for caspase- 3 is many times larger, posing limits on its use in such systems. 6XHis-tagged caspase- 6 can be easily purified in sufficient quantities for large-scale use ${ }^{7}$. Processed and purified active caspase- 6 is composed of two subunits: p14 and p19 (Fig. 3). The cloning strategy described here can be employed to engineer a caspase- 6 cleavage site in other affinity tag fusion vectors; hence, caspase- 6 can be used for the removal of affinity tags other than GST (P.K.P. and S.G., unpublished data). Here, we describe a detailed protocol under three subheadings: subcloning of gene of interest, purification of caspase- 6 and purification of pC6-2-expressed GST-free proteins. Examples of the small number of proteins purified using the pC6-2/caspase- 6 system are shown in Figure 4. The protocol for the expression and purification of caspase- 6 has been described in detail by Stennicke and Salvesen elsewhere ${ }^{7}$. 


\section{MATERIALS}

REAGENTS

-pC6-2 vector construct (Lac promoter-derived expression)

-pET23b-caspase-6 construct (T7 promoter-derived expression; for details, see ref. 7)

- Competent E. coli cells, such as XL1 blue (Stratagene, cat. no. 200249), DH5 $\alpha$ (Invitrogen, cat. no. 18258-012) and BL21(DE3) (Novagen; efficiency $10^{6}-10^{7}$ CFU per $\mu$ g DNA)

- Transformation plate: Luria-Bertani (LB) agar plate (diameter, $14 \mathrm{~cm}$ ) containing an appropriate antibiotic $\Delta$ CRITICAL While adding antibiotic, the temperature of the media should not exceed $55{ }^{\circ} \mathrm{C}$ otherwise it might be inactivated.

- $2 \times$ TY broth (1.6\% (wt/vol) Bacto tryptone, 1.0\% (wt/vol) Bacto yeast extract and $0.5 \%$ (wt/vol) $\mathrm{NaCl}$, adjusted to $\mathrm{pH} 7.0$ with $\mathrm{NaOH}$ and autoclaved)

- IPTG (Sigma, cat. no. I6758)

- Milli Q water (Millipore) or equivalent grade water

- Buffer A: $100 \mathrm{mM} \mathrm{NaCl}$ and $100 \mathrm{mM}$ Tris (pH 8.0)

- Buffer B: $500 \mathrm{mM} \mathrm{NaCl}, 20 \mathrm{mM}$ imidazole and $100 \mathrm{mM}$ Tris (pH 8.0)

- Reduced glutathione (Amersham Biosciences, cat. no. G4251), prepared as a 20-mM stock in water and stored frozen in aliquots at $-20{ }^{\circ} \mathrm{C}$

- RC DC protein assay kit (Bio-Rad, cat. no. 500-0122) to estimate proteins without interference from detergent or reducing agent

- LB broth containing $100 \mu \mathrm{g} \mathrm{ml}^{-1}$ ampicillin (Sigma)

$\cdot 6 \times$ SDS loading buffer

- Buffer X: 50 mM Tris HCl, 150 mM NaCl, 0.2\% (vol/vol) Triton X100, $1 \mathrm{mM}$ DTT and $2 \mathrm{mM}$ PMSF ! CAUTION PMSF is highly toxic and should be handled with gloves and a mask

- Lysis buffer for pC6-2-expressed proteins: $50 \mathrm{mM}$ Tris (pH 8.0), $150 \mathrm{mM}$

$\mathrm{NaCl}, 0.2 \mathrm{mg} \mathrm{ml}^{-1}$ lysozyme, $0.2 \%$ (vol/vol) Triton X100 or $0.2 \%$ (wt/vol) sodium deoxycholate

- Protease inhibitor cocktail (Roche, cat. no. 11873580001) or individual protease inhibitors (see REAGENT SETUP)

- Glutathione Sepharose 4B beads (Amersham Biosciences, cat. no. 17-0756-01)

- Sodium N-lauryl sarcosine (sarcosyl; Amersham, cat. no. 21653) prepared as $3 \%(\mathrm{wt} / \mathrm{vol}$ ) solution in water (for solubilization of the insoluble proteins in inclusion bodies)

- Caspase buffer: 20 mM PIPES, 100 mM NaCl, 10 mM DTT, 1 mM EDTA,

$0.1 \%$ (wt/vol) CHAPS and 10\% (wt/vol) sucrose ( $\mathrm{pH} \mathrm{7.2;} \mathrm{for} \mathrm{details,}$ see ref. 6)

- QIAquick gel-extraction kit (Qiagen, cat. no. 28706)

- Denaturants, such as guanidine hydrochloride $(\mathrm{GuHCl})$ or urea

(from Amersham Biosciences)

- Calf intestinal alkaline phosphatase (CIP; New England Biolabs)

-T4 DNA ligase (New England Biolabs)

- Metal-chelating Sepharose (Amersham Biosciences or Qiagen)

\section{EQUIPMENT}

- Conical Erlenmeyer flasks (preferably baffled to increase aeration), beakers and measuring cylinders of various volume capacities (50, 100 and $250 \mathrm{ml}$, and 1 and 21 )

- Two shaking incubators with cooling capacity (Thermo/New Brunswick)

- Bullet filter $(0.22 \mu \mathrm{m}$; Amicon) or PVDF syringe-driven filter unit $(0.22 \mu \mathrm{m}$;

Millipore, cat. no. SLGV033RS)

- Freezer (set at $-80{ }^{\circ} \mathrm{C}$ )

- Rotating shaker

- Plastic (Tarsons) or glass Petri dish (Borosil) of $14 \mathrm{~cm}$ diameter

- Protein gel-electrophoresis apparatus for analysis of protein quality and quantity (Protean III, BioRad)

- Sonicator (Sonics) with probes of various dimensions for working with various sample volumes I CAUTION The sonicator chamber door should be closed while performing the sonication, as prolonged exposure to ultrasonic waves might lead to deafness.

- Sepharose Q column (Amersham Biosciences)

- RC-5B plus centrifuge and SS34 rotor (Sorvall)

- Econo-column, $2 \times 2 \mathrm{ml}$ (BioRad)

- Prepacked $0.5 \mathrm{ml}$ Ni-NTA column (Qiagen)

-PD 10 column (Amersham Biosciences)

\section{REAGENT SETUP}

Protease inhibitor cocktail or individual protease inhibitors Examples include $1 \mathrm{mM}$ PMSF (Sigma; stock, $200 \mathrm{mM}$ in methanol), $1 \mu \mathrm{g} \mathrm{m}^{-1}$ aprotinin (Sigma; stock, $1 \mathrm{mg} \mathrm{m}^{-1}$ in water), $10 \mu \mathrm{M}$ antipain (Sigma; $1 \mathrm{mM}$ in methanol), $10 \mu \mathrm{M}$ leupeptin (Sigma; stock, $1 \mathrm{mM}$ in water), $10 \mu \mathrm{M}$ pepstatin (Sigma; stock, 1 $\mathrm{mM}$ in methanol), endonucleases (such as benzonase; Novagen) or DNAseI. Alternatively, viscosity can be reduced non-enzymatically by sonicating the lysates. Each protease inhibitor should be dissolved in specific solvent. A table of solvent usage for preparing stock solutions of various inhibitors is available online (http://www.serva.de/products/knowledge/061311.shtml). DTT helps in keeping protein in reduced condition and does not allow oxidation $\triangle$ CRITICAL If DNaseI is used to reduce the viscosity, add $\mathrm{CaCl}_{2}$ to the lysate at $5 \mathrm{mM}$.

IPTG Should be prepared fresh as $1 \mathrm{M}$ stock in water (working concentration ranges between 20 and $500 \mu \mathrm{M} \Delta$ CRITICAL The concentration of IPTG used can be optimized for the maximum induction and increased solubility of the protein of interest. The temperature of induction often determines the solubility of the recombinant protein; therefore, the induction of expression might be carried out at a lower temperature to enhance the solubility. The amount of culture to be used for expression depends on the specific requirement and the yield of purifiable fraction of protein, and can be determined in a pilot-scale experiment. High grade water The quality of water should be good and we recommend Milli Q (Millipore) or equivalent grade water (resistance $18 \mathrm{M} \Omega$ ) to be used for all procedures $\triangle$ CRITICAL Poor quality of water might lead to degradation of protein during the purification process.

\section{PROCEDURE}

\section{Subcloning of gene of interest into the $\mathrm{pC} 6-2$ vector}

1) Restriction enzyme-digested fragments of DNA can be ligated in-frame with the GST-encoding region of the pC6-2 vector by employing routine molecular cloning techniques ${ }^{13}$. Here we present an example of such a procedure in which we subcloned two regions of SATB1 at the BamHI site in the pC6-2 vector.

2| The DNA sequence encoding 1-204 amino acids of SATB1 was amplified using 5'BamHI-F (5'-CAACGGATCCATGGATCATTTGAAC-3') and 204BamHI-R (5'-CCATGGATCCGTCTTTCAAATCAG-3') primers, with full-length human SATB1 cDNA cloned in pBluescript as a template (pAT1146) ${ }^{14}$ under appropriate PCR conditions. The DNA sequence encoding the MD+HD region was amplified using S255-BamHI-F (5'-CACGGATCCAGTCTTTCTGAGCTATCC-3') and 2290-BamHI-R (5'-CCATGGATCCGTCTTTCAAATCAG-3') primers under appropriate PCR conditions.

3| The pC6-2 vector was digested with BamHI for $1.5 \mathrm{~h}$, heat-inactivated at $80{ }^{\circ} \mathrm{C}$ for 20 min and dephosphorylated at the $5^{\prime}$ ends by treating with CIP at $37{ }^{\circ} \mathrm{C}$ for $1 \mathrm{~h}$.

$\triangle$ CRITICAL STEP The plasmid DNA to be used for subcloning should be purified using Qiagen or an equivalent column, or by $\mathrm{CsCl}$ density gradient centrifugation to obtain mostly supercoiled DNA.

4| Both the PCR products were digested with BamHI for $1.5 \mathrm{~h}$ and heat-inactivated at $80^{\circ} \mathrm{C}$ for $20 \mathrm{~min}$.

5| The digested vector and PCR products were gel-purified using a QIAquick gel-extraction kit and ligated using T4 DNA ligase. 
! CAUTION Agarose gel containing EtBr should be handled with gloves and should be discarded at a properly assigned place. EtBr is a mutagenic and carcinogenic agent.

6| The ligation mixture was used to transform the $\mathrm{DH} 5 \alpha$ strain of $E$. coli. The orientation of the fragment in a clone was confirmed by automated DNA sequencing.

\section{Purification of caspase- 6}

7| Transform $50 \mu \mathrm{l} \mathrm{BL21(DE3)} \mathrm{competent} \mathrm{cells} \mathrm{with} 0.02 \mu \mathrm{g}$ pET23b-caspase- 6 construct and spread on LB agar containing $100 \mu \mathrm{g} \mathrm{ml}^{-1}$ ampicillin.

8| Inoculate one colony into $3 \mathrm{ml}$ of $2 \times$ TY media supplemented with $50 \mu \mathrm{g} \mathrm{ml}^{-1}$ ampicillin and incubate at $37^{\circ} \mathrm{C}$ with shaking $(200 \mathrm{rpm})$ for $12 \mathrm{~h}$.

9| Transfer $1 \mathrm{ml}$ culture into $50 \mathrm{ml}$ of $2 \times$ TY media supplemented with $50 \mu \mathrm{g} \mathrm{ml}^{-1}$ ampicillin for $2 \mathrm{~h}$ at $37^{\circ} \mathrm{C}$ with shaking (200 rpm).

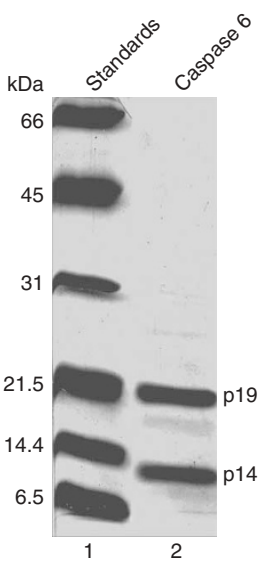

Figure 3 | SDS-PAGE analysis of affinity-purified caspase-6. An aliquot corresponding to $1 \mu \mathrm{g}$ nickel affinity column-purified caspase- 6 was resolved on a $15 \%$ SDS-polyacrylamide gel (lane 2) along with molecular mass standards (lane 1) and was visualized by staining with Coomassie brilliant blue. The two subunits of caspase- 6 are indicated as p19 and p14.

10| After $2 \mathrm{~h}$, transfer $25 \mathrm{ml}$ culture into two $500-\mathrm{ml}$ samples of $2 \times$ TY media in $2 \mathrm{l}$ baffled Erlenmeyer flasks. Shake at $37{ }^{\circ} \mathrm{C}$ and $200 \mathrm{rpm}$ until the cell density (A600) reaches 0.6-0.8.

11 Once the $A 600$ has reached between 0.6 and 0.8 , lower the temperature to $30{ }^{\circ} \mathrm{C}$, induce expression by adding $0.02 \mathrm{mM}$ IPTG and further incubate for $18 \mathrm{~h}$.

12 Harvest cells after completion of induction by centrifugation at $3,000 \mathrm{~g}$ and $4{ }^{\circ} \mathrm{C}$ for $10 \mathrm{~min}$, and resuspend in $1: 10$ volumes of buffer A immediately.

- PAUSE POINT The cell pellet can be stored at $-80{ }^{\circ} \mathrm{C}$ for up to 1 month or can be processed for purification immediately. Alternatively, the cells can be resuspended in buffer $\mathrm{A}$ and stored frozen at $-80{ }^{\circ} \mathrm{C}$ for next-day use.

13| Lyse the cells by three freeze-thaw cycles (dry ice/ethanol and $37^{\circ} \mathrm{C}$ baths) followed by sonication for 5 min to disrupt the cells and shear the genomic DNA. The sonication time and power might vary depending on the instrument and sample (e.g., a large probe, $60 \%$ output power supply and $2 \mathrm{~s}$ pulse for 2-4 min using the Sonics instrument). Subsequently, clear the lysate by centrifugation for $45 \mathrm{~min}$ at $17,000 \mathrm{~g}$ and $4{ }^{\circ} \mathrm{C}$, followed by filtration through a $0.22-\mu \mathrm{m}$ bullet filter or PVDF millex syringe-driven filter.

$\triangle$ CRITICAL STEP After centrifugation the lysate should be cleared or it can clog the Ni-NTA column and adversely affect the flow. We recommend that the lysate is passed through a $0.22-\mu \mathrm{m}$ filter.

14| Pack a 1-ml column of metal-chelating Sepharose according to the manufacturer's guidelines. Typically, a 1-ml column bed volume per liter of culture is recommended.

15| Apply the lysate to the column at a flow rate of no more than $75 \mathrm{ml}$ per $\mathrm{h}$. Wash off non-specifically bound material with 50 column volumes of buffer B (flow rate, $100 \mathrm{ml}$ per h). Elute caspase- 6 using 20 volumes of linear imidazole gradient (0-200 mM) in buffer A. Fractions are then analyzed on 15\% SDS-PAGE and pooled according to the level of purity.

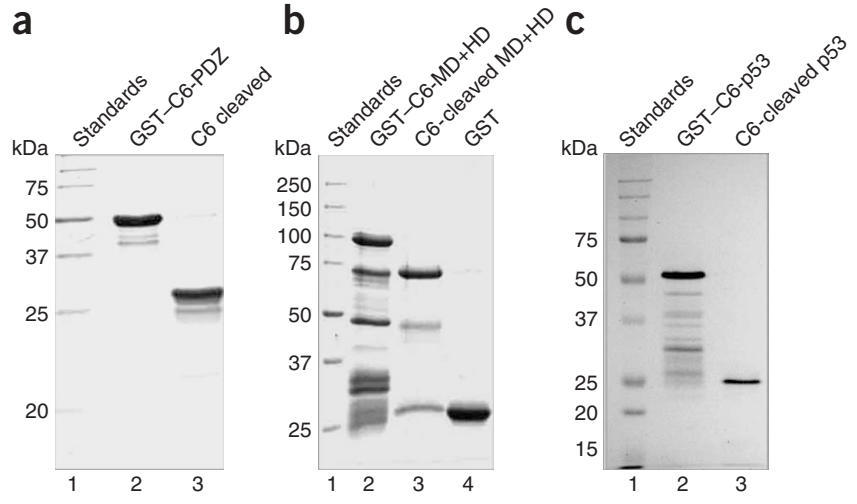

Figure 4 | Cleavage of column-bound fusion proteins releases those devoid of the GST tag. Proteins are resolved on 10-15\% SDS-PAGE for 1-1.5 h (until the bromophenol blue dye front reaches the bottom) at $100 \mathrm{~V}$ in $1 \times$ SDS running buffer and visualized by staining with Coomassie brilliant blue. (a) Purification of the PDZ domain of SATB1. Lane 1, molecular mass standards; lane 2, reduced glutathione-eluted uncleaved GST-C6-PDZ fusion protein (top band); lane 3, caspase-6-cleaved PDZ eluted with buffer $X$. (b) Purification of the C-terminal MD+HD domain of SATB1. Lane 1, molecular mass standards; lane 2, uncleaved GST-C6-MD+HD fusion protein eluted with reduced glutathione (top band); lane 3, caspase-6-cleaved MD+HD eluted with buffer X; lane 4, GST left bound to the beads after caspase- 6 cleavage and elution of MD+HD eluted with reduced glutathione. (c) Purification of the N-terminal 1-101 aa domain of p53. Lane 1, molecular mass standards; lane 2, uncleaved GST-C6-p53 fusion protein eluted using reduced glutathione (top band); lane 3, caspase-6-cleaved p53 eluted with buffer X. 
Pure fractions can be pooled and dialyzed against storage buffer containing $20 \mathrm{mM}$ Tris (pH 8.0), $150 \mathrm{mM} \mathrm{NaCl}$ and $10 \%$ ( $\mathrm{vol} / \mathrm{vol}$ ) glycerol, and stored in aliquots at $-80^{\circ} \mathrm{C}$ for at least 2 years without significant loss of activity.

$\triangle$ CRITICAL STEP The flow rate is kept low to allow the proper binding of protein to the column. The flow-through can be loaded again onto the regenerated column.

16 Additional purification is rarely necessary; however, if desired, it can be accomplished by anion exchange following dilution of the sample fivefold into ion-exchange buffer. The diluted sample is applied to a Sepharose 0 column, washed with $20 \mathrm{mM}$ Tris- $\mathrm{HCl}(\mathrm{pH} 8.0)$ until the $\mathrm{A} 280$ is $<0.01$ and then eluted with a gradient of $\mathrm{NaCl}(0-500 \mathrm{mM})$ in the same buffer.

17| Caspase-6 activity can be measured using a GST-C6 fusion protein as a substrate, or using several other methods described by Stennicke and Salvesen?

\section{Purification of pC6-2-expressed GST-free proteins}

18| Transform the XL1 blue strain of $E$. coli competent cells with the pC6-2-cloned construct using the heat-shock method and spread on an LB agar plate supplemented with $100 \mu \mathrm{g} \mathrm{ml}^{-1}$ ampicillin.

$\triangle$ CRITICAL STEP The colonies on the plate should be present in moderate numbers and should be well spaced. ? TROUBLESHOOTING

19| Inoculate a single colony in $5 \mathrm{ml} \mathrm{LB}$ media supplemented with $50 \mu \mathrm{g} \mathrm{ml}^{-1}$ ampicillin and incubate at $37^{\circ} \mathrm{C}$ for $12 \mathrm{~h}$ (overnight) with shaking (200 rpm).

20| Transfer $1 \mathrm{ml}$ culture into $250 \mathrm{ml}$ pre-warmed LB media $\left(37^{\circ} \mathrm{C}\right)$ supplemented with $50 \mu \mathrm{gl}^{-1}$ ampicillin.

21 Induce protein expression with $0.2-0.5 \mathrm{mM}$ IPTG at an $A_{600}$ of $0.6-0.8$ for $3-4 \mathrm{~h}$.

$\triangle$ CRITICAL STEP The level of induction of expression is an important variable and requires standardization of multiple parameters, such as temperature, cell density and IPTG concentration.

? TROUBLESHOOTING

22| Pellet the cells by centrifugation at $4,000 \mathrm{~g}$ and $4{ }^{\circ} \mathrm{C}$ for $10 \mathrm{~min}$. The total induced culture should be aliquoted into two parts (one small volume of $5 \mathrm{ml}$ and the remaining $245 \mathrm{ml}$ ) before centrifugation. Confirm the expression level and solubility of expressed protein by resolving the soluble extract from $5 \mathrm{ml}$ induced cell pellet on SDS-PAGE. Steps 23 to 25 describe the preparation of soluble and insoluble fractions.

- PAUSE POINT The cell pellet can be stored at $-80^{\circ} \mathrm{C}$ for up to 1 month or can be processed for purification immediately. Alternatively, cells can be resuspended in lysis buffer, kept on ice for 30 min to lyse the cell wall by lysozyme and stored frozen at $-80{ }^{\circ} \mathrm{C}$ for next-day use.

23 Resuspend the cell pellet from $5 \mathrm{ml}$ induced culture in $500 \mu \mathrm{l}$ lysis buffer, keep on ice for 10-15 min and sonicate until the sample becomes clear (e.g., miniprobe, $30 \%$ output power supply and $2 \mathrm{~s}$ pulse for 1-2 min using the Sonics instrument). Centrifuge at $17,000 \mathrm{~g}$ and $4{ }^{\circ} \mathrm{C}$ for $15 \mathrm{~min}$.

$\triangle$ CRITICAL STEP The volume of lysis buffer used for resuspension of the pellet can be varied depending on the size of the pellet obtained after centrifugation of the induced sample. The cells should be properly resuspended in the buffer.

24| Transfer the supernatant (soluble fraction) to a new tube. Add $10 \mu \mathrm{l}$ of $6 \times$ SDS loading buffer to $50 \mu \mathrm{l}$ supernatant and boil the sample for $5 \mathrm{~min}$ at $100{ }^{\circ} \mathrm{C}$.

25 Wash the pellet (insoluble fraction) by resuspending it in $1 \mathrm{ml}$ buffer $X$ and then pellet down at $17,000 \mathrm{~g}$ and $4{ }^{\circ} \mathrm{C}$ for $15 \mathrm{~min}$. The pellet can be dissolved in $600 \mu \mathrm{l}$ of $2 \times$ SDS loading buffer and boiled for $20 \mathrm{~min}$ at $100{ }^{\circ} \mathrm{C}$. Boiling for a longer time reduces the viscosity and renders the sample easy to load on gels.

26| Centrifuge the boiled samples from Steps 24 and 25 at $15,000 \mathrm{~g}$ for $10 \mathrm{~min}$ at room temperature $\left(25^{\circ} \mathrm{C}\right)$. Prepare an SDS-polyacrylamide gel and resolve the proteins by electrophoresis.

$\triangle$ CRITICAL STEP Both the samples should not be viscous before loading. Generally, soluble samples are fine and only the insoluble fractions appear viscous. If this happens, then the boiling time can be increased or brief sonication can be performed to reduce the viscosity. The bottom particulate material should be avoided and only the top layer from the sample should be loaded in the wells. Although induction can be achieved at $37^{\circ} \mathrm{C}$ to a greater extent, lowering the temperature helps to keep the metabolic activity of the cell low and also ensures that the proteins are in a more soluble form than in the inclusion bodies. Shortening the duration of induction also helps to increase the soluble fraction of protein.

? TROUBLESHOOTING

27| Fix the protein in the gel by treating the latter in fixing solution ( $50 \%(\mathrm{vol} / \mathrm{vol})$ methanol and $10 \%(\mathrm{vol} / \mathrm{vol})$ acetic acid) for 30 min with shaking. Stain for 15 min with a staining solution ( $50 \%$ (vol/vol) methanol, $10 \%$ (vol/vol) acetic acid and 
$0.25 \%$ (wt/vol) Coomassie brilliant blue) followed by two changes of the destaining solution ( $30 \%$ (vol/vol) methanol and $10 \%$ ( $\mathrm{vol} / \mathrm{vol}$ ) acetic acid). Compare the protein profile of the soluble and insoluble fractions.

$\triangle$ CRITICAL STEP GST fusion protein should ideally be obtained in a soluble fraction, as purification under denaturing conditions is not possible with GST tags (unlike 6 XHis tagged proteins). The insoluble GST fusion proteins can be purified only after the solubilization of insoluble fractions followed by refolding.

\section{? TROUBLESHOOTING}

28| After confirming that the protein is in a soluble fraction from Steps 23-27, proceed to purification using a larger volume of culture pellet. Resuspend the harvested cells (from the $245-\mathrm{ml}$ induced cell pellet; Step 21) in $12 \mathrm{ml}$ lysis buffer (10 ml lysis buffer per $\mathrm{g}$ of wet pellet can be used) and incubate on ice for $30 \mathrm{~min}$ or at room temperature for $15 \mathrm{~min}$ for adequate lysis of the cells. Lysis of the bacterial cell wall leads to an increase in viscosity.

29| The viscosity can be reduced by treatment with benzonase or DNaseI, or by sonication. We usually perform sonication until the lysate becomes clear.

$\triangle$ CRITICAL STEP Keep the sample on ice during sonication and avoid frothing. Sonication generates heat and therefore pulses should be given after a short period of incubation on ice. When using DNaseI, include $5 \mathrm{mM} \mathrm{CaCl}_{2}$ in the lysate.

30| Prepare soluble cell lysate by the centrifugation of sonicated cleared lysate at $17,000 \mathrm{~g}$ and $4{ }^{\circ} \mathrm{C}$ for 30 min.

31 Filter the lysate using a 0.22- $\mu \mathrm{m}$ PVDF syringe-driven filter. The filtered lysate can be used for binding with the glutathione Sepharose beads.

$\triangle$ CRITICAL STEP After centrifugation, the lysate should not be viscous. ? TROUBLESHOOTING

32 Alternatively, the solubilization of insoluble proteins can be achieved by the use of denaturants, such as guanidine- $\mathrm{HCl}$ (at $6 \mathrm{M})$, urea (at $8 \mathrm{M})$ or detergents such as sarcosyl $(0.3 \%$ (wt/vol)). After solubilization into any of the above denaturants, dialysis should be performed following dilution of the denaturant. The protein should be refolded using an appropriate protocol, several of which are freely available online (http://refold.med.monash.edu.au) $)^{15-17}$. The use of specific detergents has been shown to assist the refolding of carbonic anhydrase ${ }^{18,19}$ and lysozyme ${ }^{20}$. Sarkosyl has been used to solubilize and purify the E. coli heat-shock sigma factor ${ }^{21}$. We have observed the precipitation of proteins during the removal of GuHCl and urea; however, we were successful in purifying sufficient amount of proteins when $0.3 \%$ (wt/vol) sarcosyl was used for solubilization and subsequent 10 -fold dilution with buffer $X$, followed by dialysis in the same buffer (with four changes of 10 volumes of buffer $X$ each time). The presence of sarcosyl increases the solubility of GST fusion proteins but reduces their binding with glutathione beads ${ }^{22}$; when sarcosyl is removed or decreased to $0.01 \%$, the binding of GST fusion proteins to glutathione beads increases (P.K.P. and S.G., unpublished observations) and therefore purification yields are improved.

33| Incubate $200 \mu \mathrm{l}$ of glutathione Sepharose beads with $6 \mathrm{ml}$ refolded and dialyzed lysate in buffer $\mathrm{X}$ of insoluble fraction or soluble lysate of fusion protein in two separate tubes. Perform binding for $30 \mathrm{~min}$ at $4{ }^{\circ} \mathrm{C}$ with proper mixing (Rota-spin). Pack the protein-bound beads in $2 \times 2 \mathrm{ml}$ Econo-columns and wash three times with 10 volumes each of buffer $X$. One sample should be used to elute the GST fusion protein by passing $500 \mu \mathrm{l}$ of $20 \mathrm{mM}$ reduced glutathione in buffer X. Note that the protein eluted here can be used for the protein estimation by the RC DC protein assay kit and the estimated value can be used to empirically determine the amount of caspase- 6 required for on-column cleavage. The second column should be used to perform on-column caspase- 6 cleavage in $500 \mu \mathrm{l}$ caspase buffer after equilibrating the column with five volumes of caspase buffer. $\triangle$ CRITICAL STEP Different molar ratios of purified caspase- 6 enzyme to substrate GST-C6 fusion protein (1:50, 1:100, 1:150, $1: 200,1: 300,1: 400,1: 500,1: 600,1: 800$ and 1:1000) can be employed to optimize the maximum cleavage at the minimum enzyme concentration in vitro. We found that a 1:500 molar ratio of caspase-6:substrate (GST-C6-PDZ and GST-C6-MD+HD) was optimal. The amount of caspase- 6 required for the on-column cleavage was $\sim 1.4$ times greater than that required for cleaving the eluted protein.

34| An empirically determined concentration of caspase- 6 can be used to perform the cleavage of the target protein. The beadbound fusion protein in caspase buffer can be transferred to a $1.7-\mathrm{ml}$ conical microcentrifuge tube, and an appropriate amount of caspase- 6 can be added and incubated further at room temperature with mixing on a rotating shaker. The caspase-cleaved protein can be eluted by passing an additional $2 \mathrm{ml}$ buffer $X$ (reduced glutathione should not be added). The caspase- 6 used in the reaction can be removed by passing the eluted cleaved protein through a prepacked $0.5 \mathrm{ml}$ Ni-NTA column after buffer exchange in buffer A using a PD 10 column. The flow-through from the Ni-NTA column is free from contamination of caspase- 6 and can be buffer-exchanged in appropriate buffer using pre-equilibrated PD 10 columns.

$\triangle$ CRITICAL STEP To remove 6XHis-tagged caspase-6, it is essential to buffer-exchange the fusion protein and caspase- 6 protein mixture either by dialysis or using PD 10 columns that are pre-equilibrated with buffer A. DTT in the caspase buffer can reduce the charge on nickel if used directly.

? TROUBLESHOOTING

NATURE PROTOCOLS | VOL.1 N0.4 | 2006 | 1825 
PROTOCOL

\section{TIMING}

Steps 1-5: 3-4 d

Step 6: $1 \mathrm{~h}$ followed by overnight incubation

Steps 7-11: $1 \mathrm{~d}$

Steps 12-15: 5-8 h

Steps 16-17: (optional) $2 \mathrm{~d}$

Step 18: $1 \mathrm{~h}$ followed by overnight incubation

Steps 19-22: $1 \mathrm{~d}$

Steps 23-27: 5-6 h

Steps 28-31: 4-6 h

Step 33: $2 \mathrm{~h}$

Step 34: 2-3 h

\section{? TROUBLESHOOTING}

See Table 2 for troubleshooting advice.

TABLE 2 | Troubleshooting table.

\begin{tabular}{lll}
\hline Problem & Possible reasons & Solution \\
\hline Step 18: no colonies on the plate & DNA concentration is too low & Increase DNA quantity \\
& Poor competent cells & $\begin{array}{l}\text { Use freshly prepared or commercially available competent } \\
\text { cells with good transformation efficiency }\end{array}$ \\
& Poor DNA quality & $\begin{array}{l}\text { Check the DNA on agarose gel, prepare fresh plasmid } \\
\text { DNA and purify using a Qiagen column or CsCl gradient }\end{array}$ \\
$\begin{array}{l}\text { Step 18: high number or mat of } \\
\text { colonies on the plate }\end{array}$ & DNA used for transformation is too high & $\begin{array}{l}\text { Reduce the amount of DNA to be used for the } \\
\text { transformation }\end{array}$
\end{tabular}

Antibiotic on the plate is inactivated or of low concentration

Step 21: poor induction

IPTG might be old or not used optimally

Bacterial cell density is not appropriate at the time of induction of expression

Temperature of induction is not appropriate

Step 26: the protein is in the insoluble fraction

Step 26: the insoluble sample is viscous before loading

Step 27: streak in the gel instead of sharp bands

Step 31: sample is viscous and might not allow filtration through the filter membrane
Too much genomic DNA

Mainly because of high molecular weight genomic DNA, might lead to difficulty in visualizing the band corresponding to the protein of interest

Volume of lysis buffer used for resuspension is less
Make sure that the antibiotic is added when the temperature of the autoclaved LB agar is $<55^{\circ} \mathrm{C}$. Make sure that the antibiotic stock is prepared appropriately and has not expired

Confirm the expiry date, prepare fresh IPTG and standardize the concentration

Induce at different $A 600$ values ranging from 0.3 to 1.0

Optimize the temperature for expression

Try a lower temperature for the expression. Reduce the induction time. Inclusion body can be solubilized using a denaturant, such as $8 \mathrm{M}$ urea, $6 \mathrm{M}$ guanidine $\mathrm{HCl}$ or $0.2-0.4 \%$ (wt/vol) sarcosyl, followed by refolding before binding to the glutathione beads

Boil the sample for a longer time. Sonicate at a low setting to shear the genomic DNA

Sonicate the samples or treat with DNaseI during sample preparation and make sure that the sample appears clear before loading

Dilute with buffer $X$ and centrifuge again 


\section{ANTICIPATED RESULTS}

All clones generated using pC6-2 must be sequenced to verify the reading frame and nucleotide sequence (Fig. 1 ) to ensure the authenticity of the fusion protein.

Expression of caspase 6 is carried out at $30^{\circ} \mathrm{C}$ for $18 \mathrm{~h}$ using $0.02 \mathrm{mM}$ IPTG (Step 11). The yield of processed caspase- 6 may vary from batch to batch and at times a differentially induced band may not be observed while comparing the SDS-PAGE profiles of uninduced and induced cells. Therefore, after induction we directly proceed for Ni-NTA column purification. Caspase- 6 starts eluting in purer form at $150 \mathrm{mM}$ imidazole. We pool those fractions which show cleaner and intense protein bands in $15 \%$ SDS-PAGE (Fig. 3).

Occasionally, the protein eluted from the glutathione Sepharose column after caspase- 6 cleavage may show few additional bands (Fig. 4b). This is solely dependent on the nature of the protein expressed as fusion protein. In such cases, further processing may be required using gel filtration chromatography or any other affinity chromatography allowing purification of the full length protein.

ACKNOWLEDGMENTS We are grateful to $G$. Salvesen for a gift of caspase- 6 expression construct and T. Kohwi-Shigematsu for a gift of pAT1146. We thank P. Kumar for helpful comments and N. Sonawane for technical assistance. This work is supported by an intramural grant from the National Centre for Cell Science (NCCS) and the authors would like to acknowledge the support of G.C. Mishra, Director of the NCCS, for the same. P.K.P. is supported by a fellowship from the Council of Scientific and Industrial Research, New Delhi.

COMPETING INTERESTS STATEMENT The authors declare competing financial interests (see the HTML version of this article for details).

Published online at http://www.natureprotocols.com

Rights and permissions information is available online at http://npg.nature.com/ reprintsandpermissions

1. Smith, D.B. \& Johnson, K.S. Single-step purification of polypeptides expressed in Escherichia coli as fusions with glutathione $S$-transferase. Gene 67, 31-40 (1988).

2. Hunter, T., Ikebukuro, K., Bannister, W.H., Bannister, J.V. \& Hunter, G.J. The conserved residue tyrosine 34 is essential for maximal activity of iron-superoxide dismutase from Escherichia coli. Biochemistry 36, 4925-4933 (1997).

3. Jenny, R.J., Mann, K.G. \& Lundblad, R.L. A critical review of the methods for cleavage of fusion proteins with thrombin and factor Xa. Protein. Expr. Purif. 31, 1-11 (2003).

4. Guan, K.L. \& Dixon, J.E. Eukaryotic proteins expressed in Escherichia coli: an improved thrombin cleavage and purification procedure of fusion proteins with glutathione S-transferase. Anal. Biochem. 192, 262-267 (1991).

5. Salvesen, G.S. Caspases and apoptosis. Essays Biochem. 38, 9-19 (2002).

6. Salvesen, G.S. \& Dixit, V.M. Caspases: intracellular signaling by proteolysis. Cell 91, 443-446 (1997).

7. Stennicke, H.R. \& Salvesen, G.S. Caspases: preparation and characterization. Methods 17, 313-319 (1999).

8. Galande, S., Dickinson, L.A., Mian, I.S., Sikorska, M. \& Kohwi-Shigematsu, T. SATB1 cleavage by caspase 6 disrupts PDZ domain-mediated dimerization, causing detachment from chromatin early in T-cell apoptosis. Mol. Cell. Biol. 21, 5591-5604 (2001).

9. Purbey, P.K., Jayakumar, P.C., Deepalakshmi, P.D., Patole, M.S. \& Galande, S. GST fusion vector with caspase-6 cleavage site for removal of fusion tag during column purification. Biotechniques 38, 360-366 (2005).

10. Nakagomi, K., Kohwi, Y., Dickinson, L.A. \& Kohwi-Shigematsu, T. A novel DNA-binding motif in the nuclear matrix attachment DNA-binding protein SATB1. Mol. Cell. Biol. 14, 1852-1860 (1994).

11. Dickinson, L.A., Dickinson, C.D. \& Kohwi-Shigematsu, T. An atypical homeodomain in SATB1 promotes specific recognition of the key structural element in a matrix attachment region. J. Biol. Chem. 272, 11463-11470 (1997).

12. Feeney, B., Soderblom, E.J., Goshe, M.B. \& Clark, A.C. Novel protein purification system utilizing an $\mathrm{N}$-terminal fusion protein and a caspase-3 cleavable linker. Protein. Expr. Purif. 47, 311-318 (2006).

13. Sambrook, J. \& Russell, D. Molecular Cloning: A Laboratory Manual 3rd edn. Vol. 1 (Cold Spring Harbor Laboratory Press, Cold Spring Harbor, New York, 2001).
14. Dickinson, L.A., Joh, T., Kohwi, Y. \& Kohwi-Shigematsu, T. A tissue-specific MAR/ SAR DNA-binding protein with unusual binding site recognition. Cell 70, 631-645 (1992).

15. Chow, M.K. et al. The REFOLD database: a tool for the optimization of protein expression and refolding. Nucleic Acids. Res. 34, D207-D212 (2006).

16. Chow, M.K. et al. P.REFOLD: an analytical database of protein refolding methods. Protein. Expr. Purif. 46, 166-171 (2006).

17. Buckle, A.M. et al. The matrix refolded. Nat. Methods 2, 3 (2005).

18. Rozema, D. \& Gellman, S.H. Artificial chaperones: protein refolding via sequential use of detergent and cyclodextrin. J. Am. Chem. Soc. 117, 2372-2374 (1995).

19. Rozema, D. \& Gellman, S.H. Artificial chaperone-assisted refolding of carbonic anhydrase B. J. Biol. Chem. 271, 3478-3487 (1996).

20. Rozema, D. \& Gellman, S.H. Artificial chaperone-assisted refolding of denaturedreduced lysozyme: modulation of the competition between renaturation and aggregation. Biochemistry 35, 15760-15771 (1996).

21. Nguyen, L.H., Jensen, D.B. \& Burgess, R.R. Overproduction and purification of sigma 32, the Escherichia coli heat shock transcription factor. Protein. Expr. Purif. 4, 425-433 (1993).

22. Lundbäck, A.K. et al. Optimal solubilization screening strategies for GST-fusion membrane proteins. Life Science News (Amersham Biosciences) 15, 10-12 (2003).

23. Lagace, T.A., Miller, J.R. \& Ridgway, N.D. Caspase processing and nuclear export of CTP:phosphocholine cytidylyltransferase alpha during farnesol-induced apoptosis. Mol. Cell. Biol. 22, 4851-4862 (2002).

24. Nyormoi, 0 . et al. Transcription factor AP-2alpha is preferentially cleaved by caspase 6 and degraded by proteasome during tumor necrosis factor alphainduced apoptosis in breast cancer cells. Mol. Cell. Biol. 21, 4856-4867 (2001).

25. Eleouet, J.F. et al. The viral nucleocapsid protein of transmissible gastroenteritis coronavirus (TGEV) is cleaved by caspase- 6 and -7 during TGEV-induced apoptosis. J. Virol. 74, 3975-3983 (2000).

26. Ruchaud, S. et al. Caspase- 6 gene disruption reveals a requirement for lamin A cleavage in apoptotic chromatin condensation. EMBO J. 21, 1967-1977 (2002).

27. Graham, R.K. et al. Cleavage at the caspase- 6 site is required for neuronal dysfunction and degeneration due to mutant huntingtin. Cell 125, 1179-1191 (2006).

28. Werz, 0. et al. Caspase-mediated degradation of human 5-lipoxygenase in B lymphocytic cells. Proc. Natl. Acad. Sci. USA 102, 13164-13169 (2005).

29. Kalinin, A.E., Kalinin, A.E., Aho, M., Uitto, J. \& Aho, S. Breaking the connection: caspase 6 disconnects intermediate filament-binding domain of periplakin from its actin-binding N-terminal region. J. Invest. Dermatol. 124, 46-55 (2005).

30. Cohen, L.Y. et al. Notch1 antiapoptotic activity is abrogated by caspase cleavage in dying T lymphocytes. Cell. Death. Differ. 12, 243-254 (2005).

31. Horowitz, P.M. et al. caspase-6 cleavage of tau in Alzheimer's disease. J. Neurosci. 24, 7895-7902 (2004).

32. Payne, C.M. et al. Caspase- 6 mediated cleavage of guanylate cyclase alpha 1 during deoxycholate-induced apoptosis: protective role of the nitric oxide signaling module. Cell. Biol. Toxicol. 19, 373-392 (2003).

33. Chen, F., Chang, R., Trivedi, M., Capetanaki, Y. \& Cryns, V.L. Caspase proteolysis of desmin produces a dominant-negative inhibitor of intermediate filaments and promotes apoptosis. J. Biol. Chem. 278, 6848-6853 (2003). 